\title{
Transforming Growth Factor Beta Inhibits Bone Resorption in Fetal Rat Long Bone Cultures
}

\author{
J. Pfeilschifter, ${ }^{*}$ S. M. Seyedin, ${ }^{\ddagger}$ and G. R. Mundy \\ *Department of Medicine/Endocrinology, University of Texas Health Science Center, San Antonio, Texas 78284; \\ and ${ }^{\ddagger}$ Connective Tissue Research Laboratories, Collagen Corporation, Palo Alto, California 94303
}

\begin{abstract}
TGF- $\beta 1$ is a polypeptide that is abundant in bone matrix, is produced by bone cells, and modulates proliferation and differentiated functions of osteoblastic cells in vitro. TGF- $\beta 2$ is a closely related polypeptide that was originally isolated from bone matrix. TGF- $\beta 1$ has been shown previously to stimulate prostaglandin production in cultures of neonatal mouse calvariae, which causes these bones to resorb. We found similar effects with TGF- $\beta 2$. In comparison, TGF- $\beta 1$ and TGF- $\beta 2$ failed to stimulate bone resorption in fetal rat long bone cultures during a 3-d incubation period in concentrations up to 50-100 times greater than those capable of inducing bone resorption in calvariae. Incubation with TGF- $\beta 1$ for a further $3 \mathbf{d}$ decreased bone resorption up to $30 \%$. Moreover, bone resorption induced by the bone-resorbing agents IL 1 and 1,25-dihyroxyvitamin $D_{3}$ was partially or completely inhibited by TGF- $\beta 1$ and TGF- $\beta 2$ during the second half of the 6-d incubation period. Inhibition of DNA synthesis with hydroxyurea inhibited bone resorption in long bones in a similar pattern to that seen with TGF- $\beta 1$. The inhibitory effects of TGF- $\beta 1$ and TGF- $\beta 2$ on bone resorption in long bone cultures may therefore be due to inhibition of osteoclast precursor proliferation.
\end{abstract}

\section{Introduction}

Transforming growth factor beta 1 (TGF- $\beta 1)^{1}$ is a member of a recently discovered family of homologous factors that are involved in a large variety of cell functions, ranging from cell growth and differentiation to extracellular matrix production and degradation $(1,2)$. TGF- $\beta 1$ is produced by many cell types and most cells have high affinity receptors for TGF- $\beta 1$. One of the major storage sites for TGF- $\beta 1$ and the related molecule TGF- $\beta 2$ is the bone matrix (3). TGF- $\beta 2$ is also found in platelets, the human prostatic adenocarcinoma cell line, PC-3, and human glioblastoma cells $(4,6)$. Amino acid sequence analyses indicate that TGF- $\beta 1$ and TGF- $\beta 2$ differ from each other by

Address reprint requests to Dr. Gregory R. Mundy, Division of Endocrinology and Metabolism, The University of Texas Health Science Center at San Antonio, 7703 Floyd Curl Drive, San Antonio, TX 78284-7877.

Received for publication 20 November 1987 and in revised form 17 February 1988

1. Abbreviations used in this paper: $\mathrm{HU}$, hydroxyurea; TGF- $\beta$, transforming growth factor beta.

J. Clin. Invest.

(C) The American Society for Clinical Investigation, Inc. $0021-9738 / 88 / 08 / 0680 / 06 \$ 2.00$

Volume 82, August 1988, 680-685
32 amino acid substitutions, and have $>70 \%$ sequence identity (5). Recent studies indicate that there may be separate receptors for TGF- $\beta 1$ and TGF- $\beta 2$ (7). Whether there are functional differences between these receptors is unknown.

Evidence that TGF- $\beta$ may be involved in the bone resorption process has come from studies on neonatal mouse calvarial cultures in which TGF- $\beta 1$ stimulated bone resorption through an indirect mechanism by stimulating the production of $\mathrm{PGE}_{2}(8)$. Prostaglandin production has been shown to be the main mechanism for the bone-resorbing effects of many cytokines in neonatal mouse calvariae $(9,11)$. These other cytokines also stimulate bone resorption in cultures of fetal rat long bones, a widely used alternative model for the study of bone resorption in vitro. Prostaglandin-dependent stimulation, however, could not account for the stimulatory effect of many factors such as epidermal growth factor, tumor necrosis factor, or TGF alpha, indicating different mechanisms for bone resorption in the two culture systems $(12,14)$.

In this report, we show that the homologous growth regulatory peptides TGF- $\beta 1$ and TGF- $\beta 2$ inhibit bone resorption in fetal rat long bones and that their inhibitory effects on bone resorption in this system may be due to inhibition of osteoclast precursor proliferation.

\section{Methods}

Reagents. TGF- $\beta 1$ and TGF- $\beta 2$ were purified from bovine demineralized bone as previously described $(3,15)$. Recombinant IL $1 \beta$ was a gift from Dr. P. T. Lomedico (Hoffmann-La Roche, Inc., Nutley, NJ). $1,25(\mathrm{OH})_{2} \mathrm{D}_{3}$ was generously provided by $\mathrm{Dr}$. M. R. Uskokovic (Hoffmann-La Roche). Indomethacin and hydroxyurea (HU) were purchased from Sigma Chemical Co. (St. Louis, MO). All stock solutions of reagents were diluted 1:1,000 or greater in medium.

Culture technique. Fetal rat long bone cultures and neonatal mouse calvariae cultures were performed as described earlier $(16,17)$. Bones were labeled with ${ }^{45} \mathrm{Ca}$ by injecting the mothers $1 \mathrm{~d}$ before removal of the fetuses (long bones) or 1-2 d before delivery (calvariae). Long bones (radius and ulna) were dissected from 19-d-old fetal rats with removal of cartilage and fibrous tissue. Bones were cultured in $0.5 \mathrm{ml}$ of serum-free Biggers-Gwatkin-Judah (BGJ) medium (Sigma Chemical Co.) supplemented with $1 \mathrm{mg} / \mathrm{ml}$ RIA-grade BSA (Sigma Chemical Co.). Bones were incubated on steel grids at the interphase between medium and a $95 \%$ air, $5 \% \mathrm{CO}_{2}$ atmosphere at $37^{\circ} \mathrm{C}$. Calvaria halves (frontal and parietal bones) were dissected from 4-d-old neonatal mice and cultured in $1 \mathrm{ml}$ of serum-free BGJ medium containing $1 \mathrm{mg} / \mathrm{ml}$ BSA under the same conditions as described for the long bone cultures. All bones were precultured in medium for $24 \mathrm{~h}$ to remove exchangeable ${ }^{45} \mathrm{Ca}$. Bones were then cultured for $3 \mathrm{~d}$ (day 1-3) in fresh medium and after a second medium change the incubation was continued for another $3 \mathrm{~d}$ (day 4-6). TGF- $\beta 1$, TGF- $\beta 2$, indomethacin, and HU were added during the medium changes at days 1 and 4 . IL 1 and $1,25(\mathrm{OH})_{2} \mathrm{D}_{3}$ were only added at day 1 . Medium was collected after days 3 and 6 . Bones were removed from the cultures after day 6 , placed in $50 \%$ TCA for $1 \mathrm{~h}$, and ${ }^{45} \mathrm{Ca}$ in medium and TCA extract were then analyzed by liquid scintillation. Bone resorption was assessed as the 
percentage of total ${ }^{45} \mathrm{Ca}$ that was released into the medium. In some experiments, ${ }^{45} \mathrm{Ca}$ release in live bones was compared with non-cellmediated ${ }^{45} \mathrm{Ca}$ release using devitalized bones. Bones were devitalized after dissection by three cycles of freezing at $-70^{\circ} \mathrm{C}$ and thawing, and then incubated as described above.

DNA synthesis. DNA synthesis was assessed by the incorporation of $\left[{ }^{3} \mathrm{H}\right]$ thymidine into the acid-insoluble fraction of the bones as described by Lorenzo et al. (18) with some modifications. No additional cold thymidine was added to the medium. After 3 or $6 \mathrm{~d}$ in culture, bones were pulsed for $2 \mathrm{~h}$ with $1 \mu \mathrm{Ci}\left[{ }^{3} \mathrm{H}\right]$ thymidine $(20 \mathrm{Ci} / \mathrm{mM}$ sp act; ICN Radiochemicals, Div., ICN Biochemicals, Inc., Irvine, CA). Bones were then rinsed extensively in saline, blotted and placed in $1 \mathrm{ml} 5 \%$ TCA, rinsed with $1 \mathrm{ml} \mathrm{70 \%} \mathrm{ethanol,} \mathrm{air} \mathrm{dried,} \mathrm{and} \mathrm{dissolved} \mathrm{in} 1 \mathrm{ml}$ nuclear Chicago solvent (NCS) tissue solubilizer (Amersham Corp., Arlington Heights, IL) for $24 \mathrm{~h} .\left[{ }^{3} \mathrm{H}\right]$ Thymidine in the TCA extracts and the NCS digest was then assessed by liquid scintillation.

Statistics. Statistical analyses were performed by unpaired $t$ test. A two-way analysis of variance for repeated measures was used to compare TGF- $\beta 1$ and TGF- $\beta 2$ responses from individual experiments.

\section{Results}

We first examined the effects of TGF- $\beta 1$ and TGF- $\beta 2$ on bone resorption in the neonatal mouse calvariae system. Both factors increased bone resorption, but the increases were modest (Fig. 1, Table I). Small but significant increases could be achieved with $1 \mathrm{ng} / \mathrm{ml}$ TGF- $\beta 2$ and $1-2 \mathrm{ng} / \mathrm{ml}$ TGF- $\beta 1$ (Fig. 1). In some experiments, TGF- $\beta 2$ caused significant increases in bone resorption at concentrations of $0.5 \mathrm{ng} / \mathrm{ml}$. Increases in bone resorption with TGF- $\beta 1$ and TGF- $\beta 2$ could be completely inhibited by the prostaglandin synthesis inhibitor, indomethacin, during the first $3 \mathrm{~d}$ of incubation, indicating that these factors stimulated bone resorption via a prostaglandindependent mechanism, as has been shown before (9). However, in repeated experiments, indomethacin only partially inhibited TGF- $\beta 1$ - and TGF- $\beta 2$-induced bone resorption during the second half of the 6-d incubation period (Table I), suggesting that there may be another mechanism besides prostaglandin generation during this period.

We then determined if TGF- $\beta 1$ and TGF- $\beta 2$ would also increase bone resorption in the fetal rat long bone system.
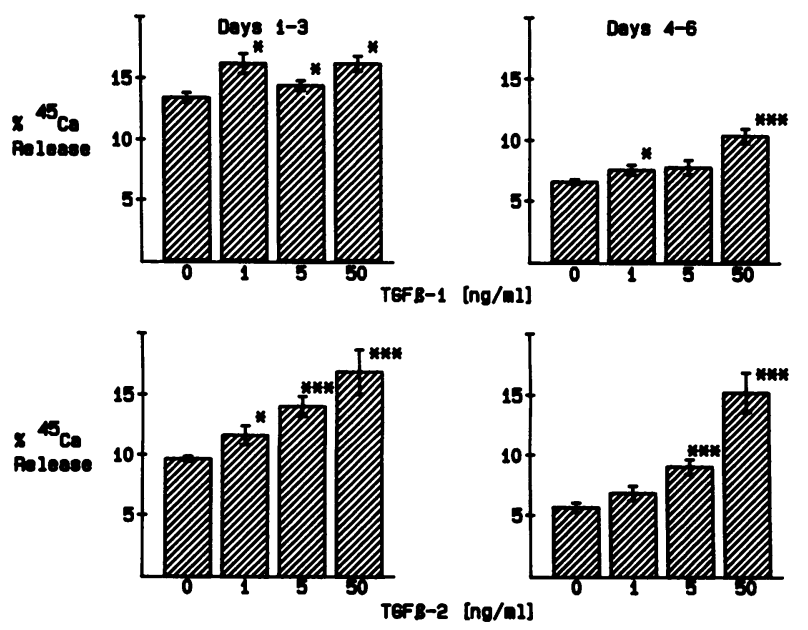

Figure 1. TGF- $\beta 1$ and TGF- $\beta 2$ stimulate ${ }^{45} \mathrm{Ca}$ release from neonatal mouse calvariae. Values are mean \pm SEM for five bones per group. *Significantly different from control, $P<0.05$. ${ }^{* * *}$ Significantly different from control, $P<0.005$.
Table I. Indomethacin Inhibits (A) TGF- $\beta 1$ - and (B) TGF- $\beta 2$ mediated ${ }^{45} \mathrm{Ca}$ Release from Neonatal Mouse Calvariae

\begin{tabular}{llc}
\hline & \multicolumn{2}{c}{${ }^{4}$ Group $\mathrm{Ca}$ percent release } \\
\cline { 2 - 3 } & \multicolumn{1}{c}{ Day $1-3$} & Day 4-6 \\
\hline A. & & \\
Control & $17.4 \pm 1.0$ & $5.6 \pm 0.4$ \\
Indomethacin $\left(10^{-6} M\right)$ & $16.9 \pm 1.3$ & $5.9 \pm 0.4$ \\
TGF- $\beta 1(10 \mathrm{ng} / \mathrm{ml})$ & $20.4 \pm 0.8^{*}$ & $8.5 \pm 0.5^{\ddagger}$ \\
TGF- $\beta 1+$ indomethacin & $16.8 \pm 1.2$ & $7.6 \pm 0.2^{\ddagger}$ \\
B. & & \\
Control & $14.2 \pm 0.6$ & $6.8 \pm 0.3$ \\
Indomethacin $\left(10^{-6} M\right)$ & $13.6 \pm 0.4$ & $6.3 \pm 0.2$ \\
TGF- $\beta 2(10 \mathrm{ng} / \mathrm{ml})$ & $17.9 \pm 0.9^{\S}$ & $11.2 \pm 0.9^{\ddagger}$ \\
TGF- $\beta 2+$ indomethacin & $14.8 \pm 0.6$ & $8.7 \pm 0.6^{*}$ \\
\hline
\end{tabular}

Values are mean \pm SEM for five bones per group.

* Significantly different from control, $P<0.05$.

${ }^{\ddagger}$ Significantly different from control, $P<0.01$.

${ }^{8}$ Significantly different from control, $P<0.005$.

TGF- $\beta 1$ and TGF- $\beta 2$ in concentrations up to $100 \mathrm{ng} / \mathrm{ml}$, however, failed to increase bone resorption (Tables II and III). On the contrary, overall analysis from eight independent experiments using $50 \mathrm{ng} / \mathrm{ml}$ TGF- $\beta 1$ showed a significant decrease in bone resorption up to $30 \%$ during the second half of the $6-d$ incubation period $(P<0.01)$. TGF- $\beta 2$ at $50 \mathrm{ng} / \mathrm{ml}$ signifcantly inhibited bone resorption in some experiments but failed to inhibit or rather slightly increased resorption in other experiments, and the overall analysis from five experiments at a concentration of $50 \mathrm{ng} / \mathrm{ml}$ revealed no significant difference from control bone resorption. Addition of indomethacin to TGF- $\beta 1$ - or TGF- $\beta 2$-treated long bones was without additional effect (Table III).

We then determined if the inhibitory effect of TGF- $\beta 1$ would be more pronounced in bones treated with bone-resorbing agents. Indeed, up to twofold increases in bone resorption caused by IL 1 and $1,25(\mathrm{OH})_{2} \mathrm{D}_{3}$ could be partially or even completely inhibited by TGF- $\beta 1$ during the second half of the incubation period, and a similar inhibition was observed with TGF- $\beta 2$ (Fig. 2). No significant decrease of bone resorp-

Table II. Effect of TGF- $\beta 1$ and TGF- $\beta 2$ on ${ }^{45} \mathrm{Ca}$ Release from Fetal Rat Long Bones

\begin{tabular}{lll}
\hline & \multicolumn{2}{c}{${ }^{45}$ Ca percent release } \\
\cline { 2 - 3 } Group & Day 1-3 & Day 4-6 \\
\hline Control & $17.4 \pm 0.8$ & $7.2 \pm 0.5$ \\
TGF- $\beta 1(1 \mathrm{ng} / \mathrm{ml})$ & $19.1 \pm 0.6$ & $7.5 \pm 0.1$ \\
TGF- $\beta 1(10 \mathrm{ng} / \mathrm{ml})$ & $17.9 \pm 0.3$ & $6.0 \pm 0.5$ \\
TGF- $\beta 1(100 \mathrm{ng} / \mathrm{ml})$ & $18.2 \pm 0.7$ & $5.2 \pm 0.5 *$ \\
TGF- $\beta 2(1 \mathrm{ng} / \mathrm{ml})$ & $17.8 \pm 0.8$ & $6.4 \pm 0.5$ \\
TGF- $\beta 2(10 \mathrm{ng} / \mathrm{ml})$ & $17.3 \pm 0.5$ & $6.7 \pm 0.5$ \\
TGF- $\beta 2(100 \mathrm{ng} / \mathrm{ml})$ & $18.6 \pm 0.3$ & $5.8 \pm 0.5$ \\
\hline
\end{tabular}

Values are mean \pm SEM for five bones per group.

* Significantly different from control, $P<0.05$. 
Table III. Effects of TGF- $\beta 1$ and TGF- $\beta 2$ on ${ }^{45} \mathrm{Ca}$ Release from Fetal Rat Long Bones in the Presence and Absence of Indomethacin

\begin{tabular}{lcc}
\hline \multirow{2}{*}{ Group } & \multicolumn{2}{c}{${ }^{45}$ Ca percent release } \\
\cline { 2 - 3 } & Day 1-3 & Day 4-6 \\
\hline Control & $15.9 \pm 0.5$ & $7.0 \pm 0.4$ \\
Indomethacin $\left(10^{-6} \mathrm{M}\right)$ & $14.8 \pm 1.0$ & $7.0 \pm 0.7$ \\
TGF- $\beta 1(50 \mathrm{ng} / \mathrm{ml})$ & $14.1 \pm 1.2$ & $5.5 \pm 0.6$ \\
TGF- $\beta 1+$ indomethacin & $14.7 \pm 0.7$ & $5.2 \pm 0.7$ \\
TGF- $\beta 2(50 \mathrm{ng} / \mathrm{ml})$ & $13.5 \pm 1.0$ & $5.1 \pm 0.6^{*}$ \\
TGF- $\beta 2+$ indomethacin & $14.4 \pm 1.0$ & $5.6 \pm 0.5$ \\
& & \\
\hline
\end{tabular}

Values are mean \pm SEM for five bones per group.

* Significantly different from control, $P<0.05$.

tion could be observed when TGF- $\beta 1$ or TGF- $\beta 2$ was added to PTH-treated cultures (data not shown). HU is also ineffective against PTH-stimulated bone resorption in this system (18). As in the calvarial system, TGF- $\beta 2$ seemed to be more potent than TGF- $\beta 1$, since it decreased IL 1 -mediated bone resorption at concentrations at which TGF- $\beta 1$ still failed to show inhibitory effects (Table IV). However, the absolute concentrations needed to inhibit IL 1-mediated resorption varied in individual experiments from 5 to $50 \mathrm{ng} / \mathrm{ml}$. Whereas TGF- $\beta 1$ was a potent inhibitor of mild increases in bone resorption caused by low concentrations of IL 1 , it was much less effective at concentrations of IL 1 that caused substantial or maximal increases in resorption (Table V). We do not know why TGF $\beta$ does not inhibit higher concentrations of IL 1 , but one possible explanation is that at higher concentrations, the major effect of IL 1 (and PTH) may be on steps in osteoclast formation and activation that are less susceptible to TGF $\beta$. For example, at higher concentrations, IL 1 (and PTH) may stimulate pre-
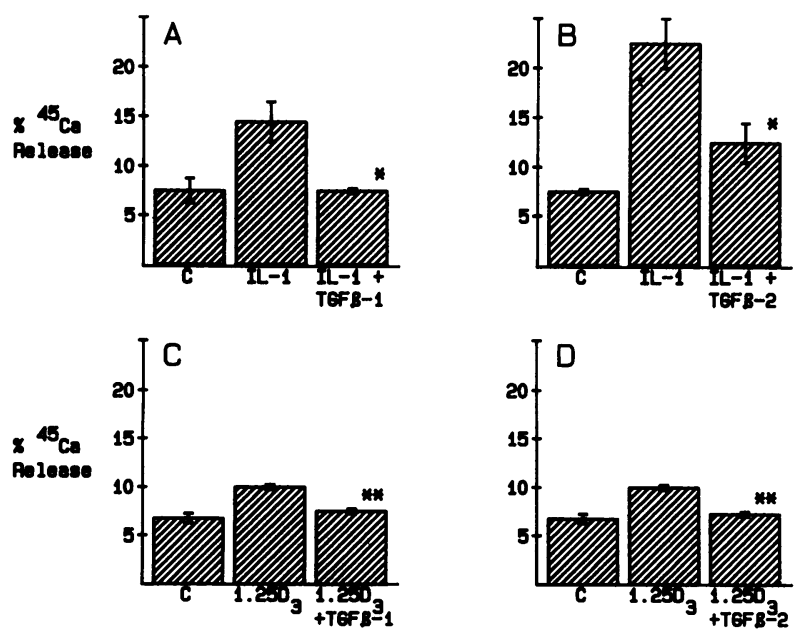

Figure 2. Inhibitory effects of TGF- $\beta 1$ and TGF- $\beta 2$ (both at 50 $\mathrm{ng} / \mathrm{ml})$ on IL $1-(10 \mathrm{U} / \mathrm{ml}$ in $A, 15 \mathrm{U} / \mathrm{ml}$ in $B)$ or $1,25(\mathrm{OH})_{2} \mathrm{D}_{3^{-}}\left(10^{-9}\right.$ $\mathrm{M})$ induced increases in ${ }^{45}$ release from fetal rat long bones ( $C$ and $D)$. Values are mean \pm SEM for five bones per group and show the release of ${ }^{45} \mathrm{Ca}$ during day 4 and 6 of incubation with TGF- $\beta 1$ and TGF- $\beta 2$. *Significantly different from IL 1 group, $P<0.02$. ${ }^{* *}$ Significantly different from $1,25(\mathrm{OH})_{2} \mathrm{D}_{3}$ group, $P<0.001$.
Table IV. Effect of TGF- $\beta 1$ and TGF- $\beta 2$ on ${ }^{45}$ Ca Release from Fetal Rat Long Bones Incubated during Days 1-3 and Days 4-6 with IL I

\begin{tabular}{|c|c|c|}
\hline \multirow[b]{2}{*}{ Group } & \multicolumn{2}{|c|}{${ }^{45} \mathrm{Ca}$ percent release } \\
\hline & Day 1-3 & Day 4-6 \\
\hline Control & $14.7 \pm 0.5$ & $7.6 \pm 0.2$ \\
\hline IL $1(15 \mathrm{U} / \mathrm{ml})$ & $35.3 \pm 3.1$ & $22.5 \pm 2.4$ \\
\hline IL $1+$ TGF- $\beta 1(6.25 \mathrm{ng} / \mathrm{ml})$ & $33.9 \pm 1.9$ & $21.6 \pm 2.1$ \\
\hline $\mathrm{IL} 1+$ TGF- $\beta 1(12.5 \mathrm{ng} / \mathrm{ml})$ & $25.0 \pm 2.7^{*}$ & $14.0 \pm 3.4^{\ddagger}$ \\
\hline IL $1+$ TGF- $\beta 1(25 n g / m l)$ & $25.2 \pm 2.7^{*}$ & $14.0 \pm 3.4^{\ddagger}$ \\
\hline IL $1+$ TGF- $\beta 2(6.25 \mathrm{ng} / \mathrm{ml})$ & $25.0 \pm 3.5^{*}$ & $12.8 \pm 2.3^{\ddagger}$ \\
\hline $\mathrm{IL} 1+$ TGF- $\beta 2(12.5 \mathrm{ng} / \mathrm{ml})$ & $27.6 \pm 2.4^{*}$ & $13.6 \pm 2.0^{\ddagger}$ \\
\hline IL $1+$ TGF- $\beta 2(25 n g / m l)$ & $24.1 \pm 3.6^{*}$ & $11.4 \pm 2.4^{\S}$ \\
\hline
\end{tabular}

Values are mean \pm SEM for five bones per group.

* Significantly different from IL 1 group, $P<0.05$.

${ }^{\ddagger}$ Significantly different from IL 1 group, $P<0.02$.

${ }^{\S}$ Significantly different from IL 1 group, $P<0.01$.

formed osteoclasts (19-21) to resorb bone. If the major effect of TGF- $\beta$ is on osteoclast formation as we propose, then inhibitory effects of TGF- $\beta$ may not be seen under these circumstances.

In most experiments, the effects of TGF- $\beta 1$ and TGF- $\beta 2$ were much more pronounced during the second half of the 6-d incubation period. TGF- $\beta 1$ is known to inhibit cell proliferation in many cell lines (22-27) and we therefore wondered whether the effects of TGF- $\beta$ in the long bone system might be due to a decrease in osteoclast precursor proliferation, which would explain the observed delayed decrease in bone resorption. We therefore compared the effects of TGF- $\beta 1$ on long bone resorption with those of $\mathrm{HU}$, a known inhibitor of DNA synthesis (28). $1 \mathrm{mM}$ HU decreased basal bone resorption and mild increases in bone resorption caused by low concentrations of IL 1 , but had little effect on resorption caused by higher concentrations of IL 1 , similar to the results we found with TGF- $\beta$ (Table VI $A$ ). Like TGF- $\beta 1$, HU was more effective during the second half of the incubation period and was capable of reducing ${ }^{45} \mathrm{Ca}$ release in otherwise untreated bones to that seen with devitalized bones (Table VI $B$ ).

Table V. Effect of TGF- $\beta 1$ on ${ }^{45} \mathrm{Ca}$ Release from Fetal Rat Long Bones Incubated with Various Concentrations of IL 1 during Days 1-3

\begin{tabular}{lcc}
\hline & \multicolumn{2}{c}{${ }^{45}$ Ca percent release } \\
\cline { 2 - 3 } \multicolumn{1}{c}{ Group } & Day 1-3 & Day 4-6 \\
\hline Control & $16.0 \pm 0.2$ & $5.8 \pm 0.5$ \\
TGF- $\beta 1(50 \mathrm{ng} / \mathrm{ml})$ & $17.0 \pm 0.5$ & $5.4 \pm 0.7$ \\
IL 1 $(100 \mathrm{U} / \mathrm{ml})$ & $73.8 \pm 2.6$ & $86.1 \pm 2.5$ \\
IL 1 $(100 \mathrm{U} / \mathrm{ml})+$ TGF- $\beta 1(50 \mathrm{ng} / \mathrm{ml})$ & $68.9 \pm 2.6$ & $71.5 \pm 5.9^{*}$ \\
IL 1 $(100 \mathrm{U} / \mathrm{ml})$ & $24.9 \pm 1.1$ & $18.4 \pm 1.4$ \\
IL 1 $(10 \mathrm{U} / \mathrm{ml})+$ TGF- $\beta 1(50 \mathrm{ng} / \mathrm{ml})$ & $24.4 \pm 2.4$ & $11.2 \pm 1.5^{\ddagger}$
\end{tabular}

Values are mean \pm SEM for five bones per group.

* Significantly different from U/ml IL 1100 group, $P<0.05$.

₹ Significantly different from $10 \mathrm{U} / \mathrm{ml}$ IL 1 group, $P<0.01$. 
Table VI. Effect of $\mathrm{HU}$ on ${ }^{45} \mathrm{Ca}$ Release from Fetal Rat Long Bones Incubated with Various Concentrations of IL 1 during $(A)$ Days 1-3 and (B) Comparison of ${ }^{45} \mathrm{Ca}$ Release from $\mathrm{HU}$-treated and from Devitalized Bones

\begin{tabular}{lcc}
\hline & \multicolumn{2}{c}{${ }^{45}$ Ca percent release } \\
\cline { 2 - 3 } Group & Day 1-3 & Day 4-6 \\
\hline A. & & \\
Control & $14.8 \pm 1.3$ & $6.0 \pm 0.4$ \\
HU $(1 \mathrm{mM})$ & $13.8 \pm 0.5$ & $3.5 \pm 0.2^{*}$ \\
IL 1 $(100 \mathrm{U} / \mathrm{ml})$ & $74.9 \pm 2.5$ & $81.0 \pm 3.0$ \\
IL 1 $(100 \mathrm{U} / \mathrm{ml})+\mathrm{HU}$ & $69.3 \pm 5.0$ & $78.2 \pm 6.3$ \\
IL $1(10 \mathrm{U} / \mathrm{ml})$ & $20.4 \pm 1.3$ & $11.1 \pm 1.5$ \\
IL 1 $(10 \mathrm{U} / \mathrm{ml})+\mathrm{HU}$ & $17.2 \pm 1.4$ & $4.4 \pm 0.5^{\ddagger}$ \\
& & \\
B. & & \\
Control & $13.0 \pm 0.5$ & $5.1 \pm 0.5$ \\
HU $(1 \mathrm{mM})$ & $11.0 \pm 0.6^{\S}$ & $3.0 \pm 0.1^{11}$ \\
Devitalized bones & $8.3 \pm 0.1^{\ddagger}$ & $3.1 \pm 0.1^{11}$ \\
\hline
\end{tabular}

Values are mean \pm SEM for five bones per group.

* Significantly different from $10 \mathrm{U} / \mathrm{ml}$ IL 1 group, $P<0.001$.

${ }^{\ddagger}$ Significantly different from control, $P<0.005$.

${ }^{\S}$ Significantly different from control, $P<0.05$.

" Significantly different from control, $P<0.005$.

A difference in proliferative capacity of osteoclast precursors might contribute to the observed difference of the effects of TGF- $\beta$ in long bones and in calvariae. We therefore tested the effect of HU in the mouse calvariae system. Compared with the long bone system, HU had no effect on baseline or stimulated resorption (Table VII) at a concentration at which DNA synthesis was $>90 \%$ inhibited (Table VIII). Since HU might lead to cell death, which could cause prostaglandin release and obscure inhibitory effects, $\mathrm{HU}$ was also tested in the presence of indomethacin. However, HU still had no effect on bone resorption (data not shown).

\section{Discussion}

TGF- $\beta 1$ stimulated bone resorption in neonatal mouse calvariae cultures in concentrations as low as $1-2 \mathrm{ng} / \mathrm{ml}$. In comparison, it did not stimulate bone resorption in fetal rat long

Table VII. Lack of Effects of $\mathrm{HU}$ on ${ }^{45} \mathrm{Ca}$ Release from Neonatal Mouse Calvariae Incubated in the Presence and Absence of Various Concentrations of IL 1 during Days $\dot{I}-3$

\begin{tabular}{lrr}
\hline \multirow{2}{*}{ Group } & \multicolumn{2}{c}{${ }^{45}$ Ca percent release } \\
\cline { 2 - 3 } & \multicolumn{1}{c}{ Day 1-3 } & \multicolumn{1}{c}{ Day 4-6 } \\
\hline Control & $12.8 \pm 0.7$ & $5.7 \pm 0.2$ \\
HU $(1 \mathrm{mM})$ & $13.1 \pm 1.4$ & $6.1 \pm 0.7$ \\
IL $1(100 \mathrm{U} / \mathrm{ml})$ & $36.0 \pm 2.4$ & $19.3 \pm 2.2$ \\
IL 1 $(100 \mathrm{U} / \mathrm{ml})+$ HU & $33.2 \pm 1.6$ & $19.7 \pm 1.0$ \\
IL 1 $(2 \mathrm{U} / \mathrm{ml})$ & $20.3 \pm 2.0$ & $7.4 \pm 0.7$ \\
IL 1 $(2 \mathrm{U} / \mathrm{ml})+$ HU & $21.3 \pm 2.0$ & $7.9 \pm 0.7$
\end{tabular}

Values are mean \pm SEM for five bones per group.
Table VIII. Effect of $1 \mathrm{mM} \mathrm{HU}$ on $\left[{ }^{3} \mathrm{H}\right]$ Thymidine Incorporation in Fetal Rat Long Bones and Neonatal Mouse Calvariae

\begin{tabular}{|c|c|c|c|}
\hline & \multirow[b]{2}{*}{ Group } & \multicolumn{2}{|c|}{${ }^{3} \mathrm{H} \mathrm{cpm} \times 10^{-2}$} \\
\hline & & Day 1-3 & Day 4-6 \\
\hline Fetal rat long bones & $\begin{array}{l}\text { Control } \\
\text { HU }(1 \mathrm{mM})\end{array}$ & $\begin{array}{c}11.1 \pm 0.7 \\
0.5 \pm 0.1^{*}\end{array}$ & $\begin{array}{c}22.3 \pm 1.6 \\
0.9 \pm 0.1^{*}\end{array}$ \\
\hline Neonatal mouse calvariae & $\begin{array}{l}\text { Control } \\
\text { HU }(1 m M)\end{array}$ & $\begin{array}{r}71.5 \pm 10.4 \\
2.2 \pm 6.2^{*}\end{array}$ & $\begin{array}{r}127.5 \pm 21.5 \\
2.6 \pm 0.2^{*}\end{array}$ \\
\hline
\end{tabular}

Values are mean \pm SEM for five bones per group.

* Significantly different from control, $P<0.001$.

bone cultures when used in concentrations up to 100 -fold higher. In this culture system, TGF- $\beta 1$ decreased basal bone resorption and partially or even completely inhibited up to twofold increases in bone resorption induced by IL 1 and $1,25(\mathrm{OH})_{2} \mathrm{D}_{3}$.

Both culture methods are well established and are the most commonly used techniques for studying bone resorption in vitro. Most factors that stimulate bone resorption or inhibit bone resorption in one organ culture system have similar overall effects on bone resorption in the other system. It has, however, become obvious over recent years that the mechanisms for stimulation or inhibition of resorption in both systems can be at least partially different. This is particularly so for many growth factors that stimulate bone resorption in calvariae by increased prostaglandin production, but do not or only partially depend on prostaglandin production for stimulation of bone resorption in fetal rat long bone (9-15). However, TGF- $\beta 1$ and TGF- $\beta 2$ are as yet the only factors that seem actually to induce opposite effects on bone resorption in the two systems.

TGF- $\beta 1$ is a potent inhibitor of proliferation in most nonmesenchymal cell lines (22-27) and recent studies have shown that TGF- $\beta 1$ also inhibits the formation of osteoclast-like multinucleated cells in long term bone marrow cultures (29), which is consistent with the data reported here. The decreases in bone resorption observed with TGF- $\beta$ in fetal rat long bones may therefore be caused by an inhibition of osteoclast precursor proliferation. A comparison between TGF- $\beta 1$ and the DNA synthesis inhibitor HU, which effectively inhibits osteoclast proliferation in long bones $(18,30)$, showed that the inhibitory effects of TGF- $\beta 1$ and $\mathrm{HU}$ in long bones were indeed similar in many aspects. Unlike calcitonin, which rapidly inhibits bone resorption by acting on mature osteoclasts (31), HU and TGF- $\beta 1$ had little effect on bone resorption during the first half of the 6-d incubation period, but both inhibited bone resorption during the second half. HU and TGF- $\beta 1$ were both able to inhibit mild increases in bone resorption induced by low concentrations of IL 1 but had little or no inhibitory effects at submaximal or maximal stimulatory concentrations or IL 1. Both agents were more effective when the bones were only pulsed with IL 1 from day 1 to day 3 instead of being exposed to IL 1 during the whole incubation period (data not shown). Therefore, TGF- $\beta 1$, like HU, apparently may inhibit the proliferation of osteoclast precursor cells.

Although inhibition of osteoclast precursor cells could be the dominant effect of TGF- $\beta 1$ on long bone resorption, it may not be the only one. The inhibitory effect of TGF- $\beta$ was 
generally less pronounced than that of $\mathrm{HU}$, but it is possible that there might be additional effects of $\mathrm{HU}$ or TGF- $\beta$. Addition of indomethacin had no further effect on bone resorption in long bones treated with up to $50 \mathrm{ng} / \mathrm{ml}$ TGF- $\beta 1$ and TGF- $\beta 2$, which makes prostaglandin-mediated effects at the concentrations of TGF- $\beta$ we used unlikely. It cannot be excluded, however, that higher concentrations of TGF- $\beta 1$ might also induce prostaglandin production in long bones.

In further contrast to fetal rat long bones, addition of $\mathrm{HU}$ at concentrations that nearly completely inhibited DNA synthesis had no effect on basal or stimulated bone resorption in calvariae in the presence and absence of indomethacin. Proliferation of osteoclast precursors, therefore, does not seem to contribute to the rate of bone resorption in calvariae.

Like TGF- $\beta 1$, TGF- $\beta 2$ stimulated bone resorption in calvariae and inhibited IL 1 - and $1,25(\mathrm{OH})_{2} \mathrm{D}_{3}$-mediated increases in bone resorption in long bones. TGF- $\beta 2$, however, was consistently more potent in calvariae and seemed to be also more potent in inhibiting IL 1-stimulated resorption in long bones. TGF- $\beta 1$ and TGF- $\beta 2$ seem to bind preferentially to different subclasses of TGF- $\beta 1$ receptors, which might explain the differences in potency (8): Both are present in the bone environment and may work together to regulate TGF- $\beta$ like effects on bone more precisely.

Most of the TGF- $\beta$ produced by bone cells and present in bone cultures is part of a biologically inactive, high molecular weight complex and needs to be dissociated to gain activity (32). Bone-resorbing agents such as PTḦ, IL 1 , and $1,25(\mathrm{OH})_{2} \mathrm{D}_{3}$ have been shown to increase TGF- $\beta$ activity in bone cultures during bone resorption (17), which may be due to activation of TGF- $\beta$ in the osteoclastic environment. TGF- $\beta 1$ has been shown to stimulate proliferation and activity of osteoblastic cells in vitro (33-36) and active TGF- $\beta$ generated during osteoclastic resorption may function as a local coupling factor and stimulate new bone formation. TGF- $\beta$ may also complete the ongoing bone resorption process by a prostaglandin-mediated stimulation of resorption by mature osteoclasts and a simultaneous suppression of the recruitment of new osteoclasts. The differences we observed in TGF- $\beta$ effects on bone resorption in fetal rat long bones and neonatal mouse calvariae may be due to differences in cell populations and the developmental stage of each culture system. However, these differences may also simply reflect differences in species or bone structure. The further characterization of these systems will therefore be important in clarifying the role of TGF- $\beta$ on bone resorption.

\section{Acknowledgments}

This work was supported by grants CA-40035 from the National Cancer Institute and AR-28149 from the National Institutes of Health. Dr. Pfeilschifter is a recipient of a fellowship from the Deutsche Forschungsgemeinschaft Bonn-Bad Godesberg, Federal Republic of Germany.

\section{References}

1. Sporn, M. B., A. B. Roberts, L. M. Wakefield, and R. K. Assoian. 1986. Transforming growth factor- $\beta$ : biological function and chemical structure. Science (Wash. DC). 233:532-534.

2 . Massague, J. 1987. The TGF- $\beta$ family of growth and differentiation factors. Cell. 49:437-438.

3. Seyedin, S. M., A. Y. Thompson, H. Bentz, D. M. Rosen, J. M.
McPherson, A. Conti, N. R. Siegel, G. R. Galluppi, and K. A. Piez. 1986. Cartilage-inducing factor A: apparent identity to transforming growth factor- $\beta$. J. Biol. Chem. 261:5693-5695.

4. Cheifetz, S., J. A. Weatherbee, M. L.-S. Tsang, J. K. Anderson, J. E. Mole, R. Lucas, and J. Massague. 1987. The transforming growth factor- $\beta$ system, a complex pattern of cross-reactive ligands and receptors. Cell. 48:409-415.

5. Maryuart, H., M. N. Lioubin, and T. I. Keda. 1987. Complete amino acid sequence of human transforming growth factor type $\beta 2 . J$. Biol. Chem. 262:12127-12131.

6. Wrann, M., S. Bodmer, R. de Martin, C. Siepl, R. Hofer-Warbinek, K. Frei, E. Hofer, and A. Fontana. 1987. T cell suppressor factor from human glioblastoma cells in a 12.5 -kd protein closely related to transforming growth factor-Beta. EMBO (Eur. Mol. Biol. Organ.) J. 6:1633-1636.

7. Segarini, P. R., A. B. Roberts, D. M. Rosen, and S. M. Seyedin. 1987. Membrane binding characteristics of two forms of transforming growth factor- $\beta$. J. Biol. Chem. 262:14655-14662.

8. Tashjian, A. H., E. F. Voelkel, M. Lazzaro; F. R. Singer, A. B. Roberts, R. Derynck, M. E. Winkler, and L. Levine. 1985. $\alpha$ and $\beta$ human trahsforming growth factors stimulate prostaglandin production and bone resorption in cultured mouse calvaria. Proc. Natl. Acad. Sci. USA. 82:4535-4538.

9. Tashjian, A. H., and L. Levine. 1978. Epidermal growth factor stimulates prostaglandin production and bone resorption in cultured mouse calvaria. Biochem. Biophys. Res. Commun. 85:966-975.

10. Tashjian, A. H., E. L. Hohmann, H. N. Antoniades, and L. Levine. 1982. Platelet-derived growth factor stimulates bone resorption via a prostaglandin-mediated mechanism. Endocrinology. 111:118-124.

11. Tashjian, A. H., E. F. Voelkel, M. Lazzaro, B. Goad, T. Bosma, and L. Levine. 1987. Tumor necrosis factor- $\alpha$ (cachectin) stimulates bone resorption in mouse calvaria via a prostaglandin-mediated mechanism. Endocrinology. 120:2029-2036.

12. Raisz, L. G., H. A. Simmons, A. L. Sandberg, and E. Canalis. 1980. Direct stimulation of bone resorption by epidermal growth factor. Endocrinology. 107:270-273.

13. Ibbotson, K. J., D. R. Twardzik, S. M. D'Souza, W. R. Hargreaves, G. J. Todaro, and G. R. Mundy. 1985. Stimulation of bone resorption in vitro by synthetic transforming growth factor-alpha. Science (Wash. DC). 228:1007-1009.

14. Stashenko, P., F. E. Dewhirst, W. J. Peros, R. L. Kent, and J. M. Ago. 1987. Synergistic interactions between interleukin-1, tumor necrosis factor, and lymphotoxin in bone resorption. J. Immunol. 138:1464-1468.

15. Seyedin, S. M., P. R. Segarini, D. M. Rosen, A. Y. Thompson, H. Bentz, and J. Graycar. 1987. Cartilage-inducing factor-B is a unique protein structurally and functionally related to transforming growth factor-B. J. Biol. Chem. 262:1946-1949.

16. Raisz, L. G. 1965. Bone resorption in tissue culture. Factors influencing the response to parathyroid hormone. J. Clin. Invest. 44:103-116.

17. Pfeilschifter, J., and G. R. Mundy. 1987. Modulation of type $\beta$ transforming growth factor activity in bone cultures by osteotropic hormones. Proc. Natl. Acad. Sci. USA. 84:2024-2028.

18. Lorenzo, J. A., J. M. Hock, and L. G. Raisz. 1983. DNA synthesis is not necessary for osteoclastic responses to parathyroid hormone in cultured fetal rat long bones. J. Clin. Invest. 72:19241929.

19. Thomson, B. M., Saklatvala, J., and Chambers, T. J. 1986. Osteoblasts mediate interleukin-1 stimulation of bone resorption by rat osteoclasts. J. Exp. Med. 164:104-112.

20. Roodman, G. D., Takahashi, N., and Mundy, G. R. 1986. Recombinant human $\gamma$-interferon ( $\gamma$-IFN) inhibits formation of osteoclast (OCL)-like cells by inhibiting the fusion of their precursors. Clin. Res. 34:552A. (Abstr.)

21. McSheehy, P. M. J., and Chambers, T. J. 1986. Osteoblast-like cells in the presence of parathyroid hormone release soluble factor that 
stimulates osteoclastic bone resorption. Endocrinology. 119:16541659.

22. Tucker, R. F., G. D. Shipley, H. L. Moses, and R. W. Holley. 1984. Growth inhibitor from BSC-1 cells closely related to type $\beta$ transforming growth factor. Science (Wash. DC). 226:705-707.

23. Roberts, A. B., M. A. Anzano, L. M. Wakefield, N. S. Roche, D. F. Stern, and M. B. Sporn. 1985. Type $\beta$ transforming growth factor: a bifunctional regulator of cellular growth. Proc. Natl. Acad. Sci. USA. 82:199-123.

24. Masui, T., L. M. Wakefield, J. F. Lechner, M. A. La Veck, M. B. Sporn, and C. C. Harris. 1986. Type beta transforming growth factor is the primary differentiation-inducing serum factor for normal human bronchial epithelial cells. Proc. Natl. Acad. Sci. USA. 83:2438-2442.

25. Baird, A., and T. Durkin. 1986. Inhibition of endothelial cell proliferation by type-beta transforming growth factor: interactions with acidic and basic fibroblast growth factors. Biochem. Biophys. Res. Commun. 138:476-482.

26. Kehrl, J. H., L. M. Wakefield, A. B. Roberts, S. Jakowlew, M. Alvarez-Mon, R. Derynch, M. B. Sporn, and A. S. Fauci. 1986. Production of transforming growth factor beta by human $T$ lymphocytes and its potential role in the regulation of T cell growth. J. Exp. Med. 163:1037-1050.

27. Ishibashi, T., S. L. Miller, and S. A. Burstein. 1987. Type $\beta$ transforming growth factor is a potent inhibitor of murine megakaryocytopoiesis in vitro. Blood. 69:1737-1741.

28. Young, C. W., and S. Hodas. 1964. Hydroxyurea: inhibitory effects of DNA metabolism. Science (Wash. DC). 146:1172-1174.
29. Chenu, C., J. Pfeilschifter, G. R. Mundy, and G. D. Roodman. 1987. Transforming growth factor- $\beta$ inhibits formation of osteoclastlike cells in long term human marrow cultures. J. Bone Min. Res. 2(Suppl. 1):253. (Abstr.)

30. Lorenzo, J. A., J. Quinton, S. Sousa, and L. G. Raisz. 1986. Effects of DNA and prostaglandin synthesis inhibitors on the stimulation of bone resorption by epidermal growth factor in fetal rat long bone cultures. J. Clin. Invest. 77:1897-1902.

31. Reynolds, J. J., and J. T. Dingle. 1968. Time course of action of calcitonin on resorbing mouse bones in vitro. Nature (Lond.). 218:1178-1179.

32. Pfeilschifter, J., L. Bonewald, and G. R. Mundy. 1987. TGF- $\beta$ is released from bone with one or more binding proteins which regulate its activity. J. Bone Min. Res. 2(Suppl. 1):249. (Abstr.)

33. Centrella, M., J. Massague, and E. Canalis. 1986. Human platelet-derived transforming growth factor- $\beta$ stimulates parameters of bone growth in fetal rat calvariae. Endocrinology. 119:2306-2312.

34. Centrella, M., T. L. McCarthy, and E. Canalis. 1987. Transforming growth factor $\beta$ is a bifunctional regulator of replication and collagen synthesis in osteoblast-enriched cell cultures from fetal rat bone. J. Biol. Chem. 262:2869-2874.

35. Pfeilschifter, J., S. M. D'Souza, and G. R. Mundy. 1987. Effects of transforming growth factor- $\beta$ on osteoblastic osteosarcoma cells. Endocrinology. 121:212-218.

36. Robey, P. G., M. F. Yound, K. C. Flanders, N. S. Roche, P. Kondaiah, J. D. Termine, M. B. Sporn, and A. B. Roberts. 1987. Osteoblasts synthesize and respond to transforming growth factor-type $\beta$ (TGF $\beta$ ) in vitro. J. Cell Biol. 105:457-463. 